JP3I (Jurnal Pengukuran Psikologi dan Pendidikan Indonesia), 7(I), 2018, 33-40

D0l: http://dx.doi.org/10.15408/p3i.v7il.12106

http://journal.uinjkt.ac.id/index.php/jp3i

\title{
RESILIENSI QUOTIONARE TESTt (RQ-TEST) ANALISIS FAKTOR VARIABEL RESILIENSI
}

\author{
Nadya Nurmalasari \\ UIN Syarif Hidayatullah Jakarta \\ Nurmalasarinadya2@gmail.com
}

\begin{abstract}
When we talk with parents, managers and CEOs about resilience, they know that resilience is the capacity to respond to difficult or challenging situations, especially with high levels of stress or traumatic events. The concept of measuring resilience developed from a new mass to a mass in the decade of the 90s (1955) Werner \& Smith developed a measuring tool to measure resilience in a work world setting called RQ-TEST (Resilience Quotionare Test). This study aims to examine the RQ-TEST factor structure model, namely resilience. The data in this study were obtained from foster children of the Bakti Pemuda Nusantara Foundation in the Banten and Bogor areas precisely from Wijaya Plus Bogor Vocational School and Pandeglang Vocational High School totaling 201 people. Meanwhile, to test the factor structure model this measurement instrument was based on factor analysis method in the form of confirmatory factor analysis (CFA), as for the calculation using LISREL 8.70 software. the results of this study show that there are a lot of measurement errors caused by items in the form of descriptors, then there are items that contain negative charges, causing a response bias.
\end{abstract}

Keywords : Test factor structure model; confirmatory factor analysis; RQ-Test

\begin{abstract}
Abstrak
Ketika kita berbicara dengan orangtua,manager,dan CEO tentang resiliensi, mereka mengetahui resiliensi adalah kapasitas untuk merespon keadaan yang sulit atau menantang terutama dengan tingkat stress yang tinggi atau kejadian-kejadian yang traumatis. Konsep pengukuran resiliensi berkembang dari massa ke massa baru pada dekade 90-an (I955) werner\&smith mengembangkan seuatu alat ukur untuk mengukur resiliensi dalam setting dunia kerja yang disebut RQTEST (Resiliensi Quotionare Test), Penelitian ini bertujuan untuk menguji model struktur faktor RQ-TEST yaitu resiliensi. Data dalam penelitian ini diperoleh dari anak asuh Yayasan Bakti Pemuda Nusantara di daerah Banten dan Bogor tepatnya dari SMK Wijaya Plus Bogor dan SMKN2 Pandeglang yang berjumlah 20I orang, Sementara itu untuk menguji model struktur faktor instrumen pengukuran ini didasari oleh metode analisis faktor berupa confirmatory factor analysis (CFA), adapun penghitungannya menggunakan software LISREL 8.70. hasil dari penelitian ini memperlihatkan bahwa terdapat banyak sekali kesalahan pengukuran disebabkan oleh item yang berupa descriptor, kemudian terdapat item yang mengandung muatan negatif sehingga menimbulkan bias respon.
\end{abstract}

Kata kunci : uji model struktur faktor, confirmatory factor analysis, $R Q$-Test 


\section{Pendahuluan}

Dalam era globalisasi ini banyak tantangan yang harus dihadapi oleh para remaja yang tinggal di kota besar, tidak terkecuali yang tinggal di daerah pedesaan. Mereka dituntut untuk mampu menghadapi berbagai kondisi baik yang positif maupun yang negatif, dengan kata lain mereka dituntut untuk memiliki nilai-nilai resiliensi di dalam diri mereka. Resiliensi berkaitan erat dengan harapan tentang masa depan dan kemampuan untuk bangkit dari keterpurukan (reaching out). Menurut Grotberg (I999) tingkat resiliensi sangat dipengaruhi oleh lingkungan sosial, rumah, sekolah dan teman sebaya. Menurut Reivich dan Shatte (2002) setidaknya terdapat tujuh faktor yang mempengaruhi resiliensi, diantarannya; regulasi emosi, (2) impulse control, (3) empathy, (4) optimisme, (5) causal analysis (6) reaching out, dan (7) self-efficacy.

Werner\&Smith (1955) mengembangkan test resiliensi yang dikembangkan dari tujuh faktor yang mempengaruhi resiliensi.

Penelitian yang dilakukan oleh Werner\&Smith terhadap I0O orang dari berbagai macam tipe pekerjaan yaitu sampel dilakukan pada perusahaan telekomunikasi yang besar kitamembandingkan RQS dari front-line employees yang telah dipromosikan oleh managernya berdasarkan rangkingnya. Skor dari manager memiliki nilai signifikansi yang tinggi,sedangkan sampel lainnya dari perusahaan management financial memiliki skor lebih rendah.

Istilah Resiliensi diintrodusir oleh Redl pada tahun 1969 dan digunakan untuk mengambarkan bagian positif dari perbedaan individual dalam respons seseorang terhadap stres dan keadaan yang merugikan, hingga tahun 1980-an istilah resiliensi diadopsi sebagai ganti dari istilah sebelumnya yang telah digunakan oleh para peneliti untuk menggambarkan fenomena, seperti "invulnerable" (kekebalan) "invincible (ketangguhan) dan "hady" (kekuatan), karena dalam proses menjadi resilien tercakup pengenalan perasaan sakit, perjuangan dan penderitaan (Henderson \& Milstein,2003).

Dewasa ini, meskipun istilah resiliensi telah diterima dan digunakan secara luas, namun tidak berarti terdapat kesesuaian dalam memberikan definisi tentang resiliensi itu,Hingga kini definisi tentang resiliensi masih terus dipermasalahkan dan bahkan belum ada konsensus tentang cakupan wilayah dari konstruk resiliensi, seperti ciri-ciri dan dinamikannya (Kaufman,dkk,1944).

Menurut Emmy E. Werner (2003), resiliensi menggambarkan tiga fenomena diantaranya:

I) Perkembangan positif yang dihasilkan oleh anak yang hidup dalam konteks "beresiko tinggi" (high risk), seperti anak yang hidup dalam kemiskinan kronis atau perlakuan kasar orang tua,

2) Kompetensi yang dimungkinkan muncul dibawah tekanan yang berkepanjangan, seperti peristiwaperistiwa disekitar perceraian orangtua mereka, dan

3) Kesembuhan dari trauma, seperti ketakutan dari peristiwa perang saudara.

Menurut Grotberg (2003) dalam sumber berbeda, Resilience for Today Gaining Strengthfrom Adversity, ” resiliensi didefinisikan sebagai seuatu fenomena atau proses yang secara relatif mencerminkan adaptasi positif, meskipun saat mengalami ancaman atau trauma yang signifikan. Luthar, Cieehetti dan Becker (2000) menyatakan bahwa resiliensi mengacu pada sebuah proses dinamis yang mencakup adaptasi yang positif dalam konteks kesengsaraan atau kemalangan.

\section{Deskripsi Instrumen Resilience Quotionare Test}

Karen Reivich\& Andrew Shatte (2002), dalam The Resilience Factor mengatakan bahwa tujuh fakto ryang ada dikembangkan dan didesain untuk melengkapi IOO responden dari berbagai jenis atau Pengukuranya dilakukan dengan mengadaptasi dari instrumen penelitian resiliensi menggunakan skala yang diadopsi dari 
Reivich and Shatte(2002) sebanyak 30 item soal. Dalam pengukurannya RQ-Test menggunakan sebuah stem yaitu :"Saya tidak mampu memanfaatkan emosi positif untuk menolong diri saya agar fokus dalam mengerjakan tugas-tugas sekolah, 'laludiikuti oleh facet-facet yang meliputi indikator dari resiliensi.

Tabel I. Blue Print Resiliensi

\begin{tabular}{|l|l|l|}
\hline Variabel & Indikator & Item/Deskriptor \\
\hline I Have & $\begin{array}{l}\text { Dukungan,hubungan yang baik } \\
\text { dengan keluarga,lingkungan sekolah, } \\
\end{array}$ & \\
\hline & yang menyenangkan,ataupun hubungan & Memiliki dukungan yang baik dari lingkungan \\
\hline & dengan orang lain diluar keluarga & \\
\hline I,AM & Kekuatan yang terdapat dalam diri seseorang & \\
\hline & kekuatan tersebut meliputi perasaan,tingkah laku, & Motivasi dalam diri, percaya diri \\
\hline I CAN & dan kepercayaan yang ada dalam dirinnya & \\
\hline & Kemampuan anak untuk melakukan hubungan & \\
\hline & sosial dan Interpersonal, memiliki kemampuan & $\begin{array}{l}\text { Dapat menyesuaikan diri, memiliki kemampuan } \\
\text { berkomunikasi dengan baik }\end{array}$ \\
\hline & untuk berkomunikasi, memecahkan masalah & \\
\hline
\end{tabular}

RQ-Test memiliki gradasi nilai tertinggi (sangat positif) sampai terendah (sangat negatif). Intense diukur melalui satu item dengan empat kategori jawaban yaitu sangat setuju,setuju,tidak setuju,sangat tidak setuju. Dengan proporsi item I7 favorable dan I3 unvavorable atau merupakan reverse item, penskoran tertinggi diberikan pada pilihan "sangat setuju" dan terendah pada pilihan "sangat tidak setuju."

Skor-skor tersebut dihitung dengan dua cara yaitu melalui item favorable dan unfavorable, untuk item favorable penskorannya yaitu : "sangat setuju" ; 4 , setuju : 3 , tidak setuju :2, sangat tidak setuju sangat tidak setuju, dan sebaliknya untuk unfavorable atau reversed item.

\section{Metode}

Untuk menguji model struktur faktor (validitas konstruk) dari RQ-Test ini didasari oleh metode analisis faktor. Adapun secara singkat analisis faktor merupakan salah satu metode untuk menguji struktur faktor atau construct validity seuatu instrumen pengukuran atau skala psikologi. Menurut Kerlinger (2006), analisis faktor merupakan metode untuk meringkas atau mengurangi sejumlah besar ukuran menjadi sejumlah ukuran yang tidak begitu banyak,yang disebut faktor-faktor dengan menyingkap faktor-faktor mana saja ukuranukurannya mengukur hal yang sama. Pengujian metode ini dilakukan melalui analisis statistik yang canggih untuk menganalisis antar hubungan dari data perilaku (Anastasi\& Urbina,2007)

Skala resiliensi yang digunakan dalam penelitian ini akan diuji struktur faktor atau validitasnya konstruknya dengan pndekatan analisis faktor berupa confirmatory factor analysis(CFA). CFA menurut Allbright dan Park (2009) adalah seuatu dorongan teori atau hipotesis, yang mana dengan CFA ini analisis faktor mungkin untuk menempatkan kebermaknaan secara substantif pada model faktor, peneliti dapat menentukkan jumlah faktor atau mengatur efek dari satu variabel laten pada variabel yang diamati dengan nilai-nilai tertentu,CFA memungkinkan peneliti untuk menguji hipotesis tentang struktur faktor tertentu misalnya, factor loading antara faktor pertama dan manifest variabel pertama adalah nol) Berikut adalah logika CFA (Umar 20I I):

I. Menetapakn teori atau model pengukuran yang hendak diuji (misal:konstruk psikologi) 
2. Menguji model fit dari teori tersebut atau dengan kata lain menguji hipotesis tentang satu atau lebih faktor (biasa berupa struktur faktor terkecil,yaitu item-item serta saling korelasi antar faktor sesuai model teori yang ditetapkan. Konsep pada tahap ini diuji dengan melihat selisih antara model teori yang ditetapkan. Konsep pada tahap ini diuji dengan melihat selisih antara model teori yang ditetapkan. Konsep pada tahap ini diuji dengan melihat selisih antara model teori yang diperoleh, untuk mengetahui ada atau tidaknya perbedaan, terlebih dahulu harus diketahui dua matriks korelasi, yaitu matriks korelasi data $(S)$ dan teori $\left(\sum\right)$ matriks.Matriks Korelasi data $(S)$ didapatkan dari polychoric corelation analysis dengan software PRELIS lalu dengan software LISREL, peneliti mengestimasi matriks teori $\left(\sum\right)$ dengan persamaan I, apabila tidak ada selisih (residu) antara data $(S)$ dengan teori $\left(\sum\right)$ maka seuatu model dapat dikatakan fit $\left(\sum-S=0\right)$ atau tidak $\left(\sum-S \neq 0\right)$.

$\sum=\wedge \Phi \wedge^{\prime}+\Theta($ persamaan I $)$

Pengujian hipotesis tersebut dapat dikatakan fit dengan memperhatikan chi-squere $\left(\chi^{2}\right)$, apabila observed chi-squere $\left(\chi^{\text {obt }}\right)$ lebih kecil daripada criticalvalue chi-squere $\left(\chi^{2} \mathrm{cv}\right)$, maka hipotesis statistic tidak ditolak $(\mathrm{HO}=0)$ yang berarti bahwa tidak ada beda antara $\mathrm{S}$ dengan $\sum$.

3. Menguji signifikansi berupa uji t,dimana nilai t dari masing-masing variabel/item signifikan ( $\mathrm{t}>\mathrm{I}, 96)$ $\mathrm{p}<0,05)$ dalam mengukur konstruk/faktor yang hendak diukur, berikut adalah kriteria item yang baik menurut pendekatan CFA(I) memiliki muatan faktor $(\lambda)$ bernilai positif,(2) item tersebut valid signifikan, $\mathrm{t}>\mathrm{I}, 96, \mathrm{p}<0,05$ dan (3) hanya memiliki korelasi antar kesalahan pengukuran item yang berada pada ambang batas dengan asumsi bahwa tidak terdapat lebih dari tiga korelasi kesalahn pengukuran antar-item,atau dengan kata lain tersebut undimensional.

Berikut prosdur dari CFA dengan It $^{\text {st }}$ order (Umar,20II) adalah sebagai berikut :

I. Bahwa ada sebuah konsep atau trait berupa kemampuan yang didefinisikan secara operasional sehingga dapat disusun pertanyaan dan pernyataan untuk mengukrnya,kemampuan ini disebut faktor sedangkan pengukuran terhadap faktor ini dilakukan melalui analisis terhadap respon atas item-itemnya.

2. Diteorikan setiap item hanya mengukur satu faktor saja,begitupun juga setiap subtes hanya mengukur satu faktor juga,artinya baik item maupun subtes bersifat unidimensional

3. Dengan data yang tersedia dapat digunakan untuk mengestimasi matriks korelasi antar item yang seharusnya diperoleh jika memang unidimensional. Matriks korelasi ini disebut sigma( $\left.\sum\right)$, kemudian dibandingkan dengan matriks dari data empiris,yang disebut matriks S.Jika teori tersebut benar (unidimensional) maka tentunnya tidak ada perbedaan antara matriks $\sum-\mathrm{S}=0$.

4. Pernyataan tersebut dijadikan hipotesis nihil yang kemudian diuji dengan chis squere, jika hasil chis squere tidak signifikan $(\mathrm{p}>0,05)$, artinya bahwa item tersebut mengukur lebih dari satu faktor atau bersifat multidimensional.Maka perlu dilakukan modifikasi terhadap model pengukuran.

5. Adapun dalam modifikasi model pengukuran dilakukan dengan cara membebaskan parameter berupa korelasi kesalahan pengukuran, Hal ini terjadi ketika seuatu item mengukur selain selain faktor yang hendak diukur. Setelah beberapa kesalahan pengukuran dibebaskan untuk saling berkorelasi maka akan diperoleh model yang fit maka model terakhir inilah yang akan digunakan pada langkah selanjutnya.

6. Jika model fit maka langkah selanjutnya menguji apakah item signifikan ataumengukur apa yang hendak diukur,dengan menggunakan t-test, jika hasil t-test tidak signifikan $(\mathrm{t}<\mathrm{I}, 96)$ maka item 
tersebut tidak signifikan dalam mengukur apa yang hendak diukur,bila perlu item yang demikian didrop dan sebaliknya.

7. Selain itu,apabila dari hasil CFA terdapat item yang koefisien muatan faktornya negatif, maka item tersebut juga harus didrop, sebab hal ini tidak sesuai dengan sifat item,yang bersifat positif (favorable).

8. Kemudian apabila terdapat korelasi partial atau korelasi kesalahan pengukuran item lainnya, maka item tersebut akan di drop, Sebab item yang demikian selain mengukur apa yang hendak diukur,ia juga mengukur hal lain (multidimensional). Adapun asumsi didrop atau tidaknya item adalah jika tidak terdapat lebih dari tiga korelasi partial atau kesalahan pengukuran yang berkorelasi dengan item lainnya.

9. Terakhir, setelah dilakukan langkah-langkah seperti yang telah disebutkan diatas. Dan mendapatkan item dengan muatan faktor signifikan ( $>1,96)$ dan positif. Maka selanjutnya itemitem yang signifikan $(t>1,96)$ dan positif tersebut akan diolah untuk nantinnya akan didapatkan faktor skornya.

Adapun data dalam penelitian ini diambil dari anak asuh Yayasan Bakti Pemuda Nusantara sejumlah 20I anak asuh, berusia I4-I8 tahun, Data tersebut dikumpulkan dalam rangka penyusunan skripsi penulis (Nadya Nurmalasari,20I3)

\section{Hasil}

Model diuji untuk mengetahui apakah data dan teori adalah sama atau fit $\left(\sum-S=0\right)$. Dalam hal ini menguji apakah benar dari kesuluruhan item pada RQ-TEST mengukur masing-masing dari keempat dimensi resiliensi yang ada,yaitu ihave,iam,ican, Berikut merupakan tabel hasil pengujian dengan pendekatan CFA ( ${ }^{\text {st }}$ order) pada RQ-TEST, dimana pada pengujian pertama tidak diperoleh model fit $\left(\sum-S \neq 0\right)$. Maka, dilakukan modifikasi terhadap model, Lalu diperoleh model fit seperti pada tabel 2 berikut.

Tabel 2. Hasil Uji Validitas Struktur Faktor atau Validita Konstruk dengan pendekatan CFA (Iºrder) Resilience Quotionare Test RQ TEST

\begin{tabular}{|c|c|c|c|c|}
\hline No & Koefisien & Standar error & Nilai t & Signifikan \\
\hline $5 \mathrm{I}$ & 0,02 & 0,08 & 0,30 & $\mathrm{X}$ \\
\hline 52 & 0,23 & 0,07 & $3, \mathrm{II}$ & V \\
\hline 54 & $-0,07$ & 0,07 & $-0,92$ & $\mathrm{X}$ \\
\hline 55 & 0,29 & 0,08 & 3,72 & V \\
\hline 56 & 0,46 & 0,07 & 6,40 & V \\
\hline 57 & $-0,36$ & 0,07 & $-4,94$ & $\mathrm{X}$ \\
\hline 58 & 0,35 & 0,07 & $4,7 \mathrm{I}$ & V \\
\hline 59 & 0,55 & 0,07 & 7,94 & V \\
\hline 60 & 0,58 & 0,07 & 8,56 & V \\
\hline $6 I$ & 0,55 & 0,07 & 7,73 & V \\
\hline 62 & $0,5 \mathrm{I}$ & 0,07 & 7,47 & V \\
\hline 63 & $0,4 \mathrm{I}$ & 0,07 & 5,59 & V \\
\hline 64 & 0,37 & 0,07 & 4,99 & V \\
\hline 65 & $-0,07$ & 0,08 & $-0,87$ & $\mathrm{X}$ \\
\hline 66 & $0,4 \mathrm{I}$ & 0,07 & 5,57 & V \\
\hline
\end{tabular}




\begin{tabular}{|c|c|c|c|c|}
\hline 67 & 0,50 & 0,07 & 7,23 & $\mathrm{~V}$ \\
\hline 69 & $-0,02$ & 0,07 & $-0,29$ & X \\
\hline $7 \mathrm{I}$ & $-0,50$ & 0,07 & $-6,96$ & $X$ \\
\hline 72 & $-0,06$ & 0,08 & $-0,73$ & $\mathrm{X}$ \\
\hline 74 & $0,5 \mathrm{I}$ & 0,07 & 7,49 & $\mathrm{~V}$ \\
\hline 75 & 0,35 & 0,08 & 4,65 & $\mathrm{~V}$ \\
\hline 77 & 0,38 & 0,07 & 5,24 & $\mathrm{~V}$ \\
\hline 78 & $-0,05$ & 0,08 & $-0,66$ & $X$ \\
\hline 80 & 0,34 & 0,07 & 4,50 & $\mathrm{~V}$ \\
\hline $8 \mathrm{I}$ & $-0,17$ & 0,08 & $-2,2 \mathrm{I}$ & $\mathrm{X}$ \\
\hline 82 & 0,35 & 0,08 & 4,67 & $\mathrm{~V}$ \\
\hline 83 & $-0,06$ & 0,07 & $-0,77$ & $\mathrm{X}$ \\
\hline 85 & $0,3 \mathrm{I}$ & 0,07 & 4,16 & $\mathrm{~V}$ \\
\hline 94 & 0,36 & 0,07 & 4,75 & $\mathrm{~V}$ \\
\hline I02 & $0,2 \mathrm{I}$ & 0,08 & 2,70 & $\mathrm{~V}$ \\
\hline
\end{tabular}

Pada tabel di atasdapatdilihatterdapat IOitem yang tidak signifikan dengan nilai t-value pada masingmasing koefisienmuatanfaktor item sebagai berikut :

(I) Item 5 I dengan nilai koefisien faktor item 0,30 nilai tersebut tidak signifikan karena kurang dari 1,96

(2) Item 54 dengan nilai koefisien faktor item -0,92 nilai tersebut tidak signifikan karena bermuatan negatif dan kurang dari I,96

(3) Item 55 dengan nilai koefisien faktor item -0,87 nilai tersebut tidak signifikan karena bermuatan negatif dan kurang dari I,96

(4) Item 57 dengan nilai keofisien faktor item -4,94 nilai tersebut tidak signifikan karena bermuatan negatif dan kurang dari I,96

(5) Item 69 dengan nilai koefisien faktor item -0,29 nilai tersebut tidak signifikan karena bermuatan negatif dan kurang dari I,96

(6) Item 7I dengan nilai koefisien faktor item -6,96 nilai tersebut tidak signifikan karena bermuatan negatif dan kurang dari I,96

(7) Item 72 dengan nilai koefisien faktor item -0,73 nilai tersebut tidak signifikan karena bermuatan negatif dan kurang dari I,96

(8) Item 78 dengan nilai koefisien faktor item -0,66 nilai tersebut tidak signifikan karena bermuatan negatif dan kurang dari I,96.

(9) Item 8I dengan nilai koefisien faktor item -2,2I nilai tersebut tidak signifikan karena bermuatan negatif dan kurang dari I,96.

(I0) Item 83 dengan nilai koefisien faktor item -0,77 nilai tersebut tidak signifikan karena bermuatan negatif dan kurang dari I,96

Sedangkan muatan faktor 20 item lainnya bernilai signifikan dengan nilai koefisien faktor item bermuatan positif dan lebih besar dari I,96.dengan demikian IO item yang telah diuraikan diatas didrop. 


\section{Diskusi}

Instrumen pengukuran Resiliensce Quotionare Test RQ-TEST ini telah digunakan pada penelitian sebelumnya oleh werner,smith kepada 100 orang dengan berbagai tipe pekerjaan (dalam reivich and shatte 2002). Untuk mengukur resiliensi dan secara konsisten tetap mempertahankan validitas dan reliabilitas yang tinggi dan alpha cronbach berkisar antara 0,90-0,95. Akan tetapi dari hasil uji struktur faktor atau validitas konstruk dengan menggunakan pendekatan analisis faktor berupa confirmatory factor anlysis (CFA) terdapat banyak sekali korelasi kesalahan pengukuran antar item atau dengan kata lain sebagian besar item tidak hanya mengukur satu faktor saja yaitu resiliensi akan tetapi kemungkinan besar juga mengukur konstruk psikologi lainnya, hal ini mungkin saja dikarenakan hampir setiap indikator yang digunakan sebagai konstruk pada sebagian besar item tersebut memiliki kesamaan makan sehingga responden cenderung mempersepsikan setiap item tersebut sama. Sehingga dapat disimpulkan bahwa model satu faktor yang diteorikan oleh instrumen pengukuran RQ-TEST ini dapat diterima tetapi tidak semua item dapat digunakan artinnya disesuaikan dengan sampelnya.

Model satu faktor yang diteorikan tersebut baru dapat dikatakan sesuai apabila item-item yang tidak memenuhi kriteria seperti yang telah disebutkan sebelumnya, yaitu (I) memiliki muatan faktor $(\lambda)$ bernilai positif, (2) item tersebut valid (signifikan,t $>$ I,96,p $<0,05$ ) dan (3) hanya memiliki korelasi antar kesalahan pengukuran item yang berada pada ambang batas dengan asumsi bahwa tidak terdapat lebih dari tiga korelasi kesalahan pengukuran antar-item, atau dengan kata lain item tersebut bersifat unidimensional, tidak diikutsertakan. Dengan kata lain cukup hanya dengan mengikutsertakan item-item yang memenuhi kriteria saja (batas toleransi kesalahan pengukuran antar-item), yaitu itemnomor: $52,55,56,58,59,60,61,62,63,64,66,67,74,75,78,82,85,94,102$, item tersebut sudah cukup mewakili konstruk resiliensi tersebut.

\section{Penutup}

Untuk itu peneliti menilai bahwa hanya itemnomor 52, 55, 56, 58, 59, 60, 61, 62, 63, 64, 66, 67, 74, 75, $78,82,85,94$, I02, item itu saja yang cukup digunakan oleh peneliti lain apabila ingin mengukur resiliensi pada individu. Hal ini dikarenakan item tersebut memenuhi kriteria-kriteria sebagai item yang baik, yaitu (I) memiliki muatan faktor positif,(2) valid (signifikan,t>I,96) dan (3) hanya memiliki korelasi antar kesalahan pengukuran item yang berada pada ambang batas dengan asumsi bahwa tidak terdapat lebih dari empat enam korelasi kesalahan pengukuran antar item satu dengan item lainnya, atau dengan kata lain item tersebut bersifat undimensional, sedangkan item lainnya bersifat multidimensional atau tidak hanya mengukur satu faktor saja dalam hal ini faktor resiliensi, sehingga tidak perlu diikutsertakan sebagai item saat hendak mengukur konstruk resiliensi tersebut.

\section{Daftar Pustaka}

Ai Siebert (2005) The resiliency advantage master change Publisher Inc Sanfransisco

Amy Beth Collins (2009) Life experiences and resilience in college students a relationsheep influenced by hope and mindfullness dysertation A\&M Texas University

Dasmita. (2009).Psikologi perkembangan peserta didik remaja. Bandung: Rosdakarya

Karen reivich, Phd \& Andrew Shatte,Ph.D (2002) The resilience factor 7 essential skills for overcoming life's inevitable obstacles, united state of America 
Michlle Dawson\&Julie Ann Pooley (2013) Resilience : the role of optimism, perceived parental autonomy support and perceived social support in first year Journal of Education and Training Studies vol I no 2 oktober 2013

Nasution. (2003).Metode (Penelitian Ilmiah). Bumi Aksara

Umar,Jahja (20I I), Bahan kuliah Psikometri UIN Jakarta. 